\title{
SPECULATIVE FIELDS: \\ Property in the Shadow of Post-Conflict Colombia
}

\section{MEGHAN L. MORRIS \\ American Bar Foundation}

(D) https:/ / orcid.org/0000-0001-8052-6886

We walked through empty pasture after empty pasture, sweating in the hot sun of Urabá, a region in northwestern Colombia. We were headed toward the small plot that Ernesto and his wife Cristina had planted with rice, corn, and other crops. ${ }^{1}$ They had been working the plot quietly for several years, unnoticed by the rancher who had pastures in the area, until some teak trees they planted grew tall. Cristina claimed that these ranchers, with the help of the paracos (paramilitaries), had forced her and other small farmers to sell their farms cheaply in 1997, consolidating them into ranchland. More than ten years later, she and Ernesto had returned to reclaim the plot, now surrounded by pastures. Although she had received threats of removal from ranch hands, Cristina was triumphant. "Tengo la posesión! [I have possession!]," she exclaimed. She hoped to have this possession formalized soon, through a claim she had filed with the national land restitution program. Designed to return and title land to people who lost it during Colombia's armed conflict, the program had received thousands of claims in Urabá — as well as opposition from ranchers, who considered the land to be theirs.

On arrival, we took shade under the rice hanging beneath a black plastic sheet that Ernesto had secured to wooden posts - a sturdy cambuche, the hut that farmers taking a new plot would build to help establish possession. Cristina invited 
me behind the cambuche to a tree. There was a pair of bright green parrots, staring sideways at us with round red eyes. CORRA! CORRA! (RUN! RUN!), they yelled. Cristina laughed, cooing that she had missed them. I felt rattled, thinking about the violent circumstances in which the parrots had learned this warning.

Land restitution intervened in layered regimes of property and war in landscapes like these. ${ }^{2}$ It sought to address land dispossession and abandonment, long documented as both a consequence of the Colombian conflict as well as one of its root causes (CMH 2010). The restitution agency aimed to return more than six million hectares of land to war victims, including some of Colombia's more than five million internally displaced people.

As the country attempted to end its decades-long conflict, in part through talks leading to the 2016 peace agreement between the government and the guerrillas of the Revolutionary Armed Forces of Colombia (FARC), the state billed reparations for victims as central to a new era: the "post-conflict." Many such initiatives, like restitution, involved the reordering of property; they aimed to settle both people and land claims, thereby paving the path to peace.

The time, however, was also one of war on many levels, from processes of land possession and dispossession like those on Cristina and Ernesto's farm, to daily news of paramilitary death threats, guerrilla violence, narco-trafficking, and political corruption. Even as the government prepared to declare the arrival of the post-conflict on signing the peace agreement, public debate revolved around whether the post-conflict would indeed arrive, or whether it would simply be a posacuerdo (post-agreement) era, with peace deferred further into the future. Peace indeed was postponed once again after the agreement was signed, as an October 2016 referendum on the accord failed by a slim margin. The Colombian Congress later approved a revised agreement, but opponents walked out of Congress before the vote. The possibilities of peace amid the fractured political landscape remain uncertain.

The focus on the agreement as an event punctuating time speaks to Jane I. Guyer's (2007) notion that the "near future" has been reoriented around dates and events. At the same time, the ambiguities around whether peace had arrived did not evacuate the near future, as Guyer suggests, but rather rendered it expandable, extending into an uncertain horizon. In this near future, there persists a suspension between conflict and post-conflict that has become the pervasive condition of a country attempting for decades to make peace in the middle of war (Bergquist, Peñaranda, and Sánchez 2001). Akin to Lochlann Jain's (2007) analysis of the “can- 
cer survivor" — a term that holds both life and death within it — war and peace define this temporal space simultaneously.

I call this uncertain, elastic temporal space the shadow of the post-conflict. I use shadow to evoke the temporal ambiguity of the post-conflict, which can be understood both as a time yet to come and the condition of the present. Its shadow is thus cast in multiple directions, changing shape and extension as peace is deferred, accorded, and retracted. This term borrows loosely from Robert H. Mnookin and Lewis Kornhauser's (1979) notion of “bargaining in the shadow of the law," which describes how divorcing couples negotiate outside of court based on their conjectures about what they would be allocated if they went to trial. I suggest that the shadow of the post-conflict creates fertile ground for acts of possession and dispossession that have a speculative relationship to legal regimes oriented toward peace. The shadow of the post-conflict, in this sense, evokes not only the ambiguity between war and peace — as post-conflict scholars have long observed (Nordstrom 2004; Theidon 2007; Nelson 2009; McAllister and Nelson 2013) — but the speculative nature of politics within that space of ambiguity.

I follow Austin Zeiderman's $(2016,164)$ emphasis on the importance of temporal politics "both as a domain of social control and as a terrain of political possibility" in this analysis. While Zeiderman, like other anthropologists of anticipatory regimes (Lakoff and Collier 2008), theorizes the temporal orientation toward risk of future harm, I explore the orientation toward a potential future peace, even as war persists. I examine the ways in which people reorient their action in turn, speculating on markets, legal regimes, and regimes of violence that might emerge from property reallocations.

The current analysis is based on fieldwork between 2012 and 2015, land restitution's initial years - a particularly ripe time for speculation. While there were critiques of the limits of restitution during its formation and early years (UprimnyYepes and Sánchez 2010; HRW 2013), a sense also prevailed among bureaucrats, claimants, and those opposed to restitution that the process might effect substantive reallocations of property over rural land. The timing of the fieldwork thus offered a vantage point onto speculation at a time of particular uncertainty about both property and peace. Through ethnographic work with actors in Urabá-including land claimants, large landholders, state bureaucrats, former armed actors, and activists - I analyze how speculation was enacted by and between different groups.

I use speculation in its dual meaning, defined in the Oxford English Dictionary $(O E D)$ as "investment in stocks, property, or other ventures in the hope of gain 
but with the risk of loss" and "the forming of a theory or conjecture without firm evidence." In this double sense, claimants, paramilitaries, and landowners engaged in speculative activities that constituted investments in land, as well as conjectures on what they might be granted — or might lose — under a post-conflict peace.

These actors engaged in speculation to manage uncertainties about peace, as it was continually deferred into the future. As peace is repeatedly postponed, what speculative forms take shape? How do they relate to the state promise to bring peace through property? What does this tell us about the role of speculation on land and property in other ambiguously post-conflict sites (Shneiderman and Snellinger 2014)?

As a focus of government intervention in preparation for the post-conflict, and as the issue broadly believed to be the root of the conflict, land was where the possibilities for war and peace were grounded - for claimants, but also for restitution bureaucrats, large landowners, and armed actors. In a moment of fundamental uncertainty about peace, actors reconfigured historical strategies for staking a speculative claim on the future through land. These strategies joined multiple forms of property, from possession to title, that were at play around restitution efforts.

The anthropology of speculation offers a rich set of resources for conceptualizing the imbrication of past, present, and future that these strategies perform. Guyer $(2007,411)$ called for anthropologists to move beyond "the past in the present" to bring ideologies of the future into view. Much of the subsequent literature on speculation does precisely that, orienting itself toward futures and how they rework the present (Fortun 2008). The literature on post-conflict, on the other hand, frequently orients itself toward memory and how it shapes present politics (Rojas Pérez 2008; Nelson 2009; Theidon 2013).

The conceptualization of speculation in the shadow of post-conflict Colombia demands a theory that privileges neither pasts nor futures, but rather accounts for the ways that past, present, and future fold into each other. As opposed to other theories of the temporality of uncertain political transition — which describe the sense of being "stranded in the present" (Scott 2014, 67) — I suggest that one of the hallmarks of "post-conflict" temporality may be the constant tacking between past, present, and future. Vincanne Adams, Michelle Murphy, and Adele E. Clarke (2009) have called this temporal tacking "abduction," a process of determining a course of action by taking into account both past data and anticipated futures.

At the same time, the temporalities implied in these processes follow more twisted paths and discontinuous folds than the process of abduction suggests. 
Karen Barad's work on spacetime offers a conceptual entry point into these temporalities and the role of the material within them, arguing that "quantum discontinuities" are produced through the folding together of past and future that occurs in the making of matter and material boundaries. Barad suggests that the past never lies entirely behind us, and that the present does not simply produce a certain future; rather, the reconfiguration of the material world brings past and future into discontinuous articulation (Barad 2007, 234). I draw on this approach, along with the divergent temporal orientations of the anthropology of speculation and post-conflict, to consider the particular temporal disposition that defines the shadow of post-conflict Colombia and pervades politics within it.

I take land - particularly the physical possession of land - as a central modality through which this temporal folding occurs as people speculate in the shadow of the post-conflict. The literature on speculation has largely not focused on land or property, examining instead financial markets (Ho 2009; Zaloom 2009) and markets in oil and genomics (Fortun 2008; Weszkalnys 2015), with some exceptions considering land (Campbell 2015) and the legal aspects of speculation (Peterson 2014). How might we understand speculation differently if we begin with land?

While the war rendered people's relationships to land unstable and risky, people still perceived property over land to offer a concrete, grounded claim to power and place in the context of widespread uncertainty. This made it an ideal object of speculation. This speculation was related to land markets, but also occurred as a form of conjecture about future legal regimes, as well as regimes of violence intertwined with land. Possession, in particular, sat at the boundary of the market, and at the blurry edges of legality and violence, making it a critical speculative strategy. People reworked historical forms of land possession to negotiate the uncertainties around these regimes - and, more broadly, the space between war and peace in which they proliferated. As with the ambiguity between life and death in Jain's (2007) "living in prognosis," the movement between future and past rendered material the ambiguous temporal space between war and peace, as the promise of peace was continually deferred.

In the first section of the article, I draw on ethnographic fieldwork in Urabá to investigate how diverse actors speculated on legal and market regimes, as well as regimes of violence, by taking land. I then discuss a historical speculative form central to the conflict that later took on new significance: invasión (land invasion). ${ }^{3}$ In the final section, I examine the forms of speculation that emerged as the reor- 
dering of property through restitution took shape in the expanding shadow of the post-conflict.

\section{SPECULATIVE POSSESSION}

Cristina had not been to the farm for months_- "since they threatened me," she said. Like other land claimants receiving death threats, she lived in town, which allowed her to advance claims with state agencies. But this setting proved only marginally safer than living near the farm, where she figured that if they killed her, at least "everyone would know who did it."

At the plot, we rested on tree stumps. I asked Cristina why she thought the rancher had not kicked them off. She thought that maybe they had given up, since the plot was so small. Other farmers who had been her neighbors before their displacement were happy she had this plot, she said, "because we're protecting their right with our possession!" Their possession served as proof, of both past possession and future right. While it did not guarantee against removal, Cristina surmised that the longer they farmed it, the less likely they would be kicked off. When the ranchers saw their teak growing, Cristina said, "they see a future there" - her future on the plot.

Later, Ernesto asked, "how many years do you need with posesión? Fifteen? Twenty? If the rancher were going to remove us, he would have done it a long time ago." Ernesto understood that possession, combined with time on the plot, might mean something more. According to Colombia's Civil Code, possession is tenure "with intention of ownership." If possessors demonstrate peaceful acquisition and uninterrupted possession for a number of years, provided the plot meets certain conditions, they may solicit title.

The possibility of having a greater legal claim to the plot was on Ernesto's mind. They farmed for food, but also to bolster past and future claims to the plot, despite the risks of farming in the middle of the rancher's pastures. This approach implied multiple forms of speculation - on the possibility they would meet requirements for title, on the likelihood their possession would be determined a legal route to title rather than an illegal trespass, and on the risk of violent retributions against them.

These tenuous, layered claims to the plot formed part of a historical process of taking land to stake claims on the future in moments of uncertainty. I refer to this process as speculative possession. In this section, I draw on the recent history of the area around Ernesto and Cristina's plot to illustrate how speculative possession has been conceived and enacted in Urabá. 
Cristina pointed out scattered fruit trees in the pastures - coconut, mango, avocado — planted by colonists like her, she said. "Sembramos comida [We planted food]," she emphasized, differentiating small farmers from ranchers who let pastures lie fallow. In the 1970s, colonists had come looking for land in Urabá, known for its rich soils and remaining baldios (idle state lands). Despite the historic presence of indigenous and black communities, they found large stretches not directly inhabited, and took possession.

The area, however, was a site of increasing violence. Rebels from the FARC controlled many new villages, and targeted farmers unwilling to cooperate. In the late 1980s, paramilitary groups emerged in the neighboring department of Córdoba, formed by landholding elites and narco-traffickers to combat left-wing guerrillas, which had targeted them and their properties (Duncan 2006). These groups soon moved into Urabá. Frustrated by kidnappings and extortion by the FARC and land invasions by small farmers, as well as state responses they perceived as ineffective, some local landholders became involved in the paramilitary project. As paramilitaries expanded, the violence worsened, bit by bit: a neighbor murdered, a relative disappeared. Paramilitaries rounded up villagers for interrogation, killing some on suspicion of being guerrilla collaborators. This period proved so bloody that local small farmers uniformly call the late 1990s la violencia (the violence), referring to the peak of violent confrontation in the region (as opposed to the midtwentieth-century political violence generally known as La Violencia). ${ }^{4}$

Eventually, Urabá became the paramilitaries' center of operations, where they built models for collaboration with state and private actors (López 2007; Romero 2011). One of their aims was to protect large landholders and their properties, which they carried out in part through "security cooperatives" called CONVIVIR, a legal structure for coordination between the military and the population to confront guerrilla forces. The CONVIVIR eventually served as fronts for paramilitary operations (López 2007), some receiving funds from landholders. They facilitated not just counterinsurgency but also paramilitary control of regions like Urabá for narco-trafficking (Duncan 2006, 2014). The establishment of the CONVIVIR constituted an element of the eventual parapolitica (parapolitics) scandal, in which hundreds of government officials were investigated — and some later convicted - for links to paramilitaries and narco-traffickers. The involvement of the armed forces in the scandal put in question billions in U.S. military aid to Colombia (Tate 2015).

These collaborative models contributed to a lack of clarity around relationships between ranchers and paramilitaries. Some people simply equated them, 
while others thought some ranchers might be paramilitaries but were not sure, and still others argued that certain ranchers had nothing to do with paramilitarism. This uncertainty around elites' potential simultaneous roles fed a climate of suspicion, as well as people's speculation on violence when they made restitution claims to plots held by ranchers. ${ }^{5}$

The violence in the area around Ernesto and Cristina's farm reached its peak in 1997. Paramilitaries murdered more farmers, and people began to flee to Urabá's larger towns or cities like Medellín. Simultaneously, what farmers called "commissions" arrived looking to purchase land from locals. Some came unarmed, but others carried arms or were accompanied by individuals locals recognized as paramilitaries. The prices offered were low, but many sold, afraid of the violence and eager to get something for the land before leaving. Those who stayed longer often found themselves forced to sell. "Si no nos quiere vender, la viuda nos vende más barato [If you don't want to sell it to us, your widow will sell it cheaper]," some commissions would warn farmers holding out.

In the ensuing few years, a tremendous shift in ownership occurred, with a handful of local and regional elites taking possession of land. Titles were signed over for some farms, but many did not have registered title. Some farmers had applied for title, but never received it prior to la violencia, while others never did the paperwork. Still others had received title, but failed to register it. Titles, however, later magically appeared for some plots: the product of a "pirate" Urabá office of the state rural development agency that produced backdated false titles for some farms transferred to ranchers. These transactions would often be followed by a series of plot transfers to conceal illicit acquisition; Teo Ballvé (2013) aptly calls this process "land laundering."

The new landholders consolidated their acquisitions into large ranches, populating some fields with cows and buffaloes, while leaving many empty. Pastures and cattle became indicators of possession by these new owners, as opposed to the corn, rice, and fruit trees planted by small farmers. This change shifted not only land use but also the ways that possessors materialized temporal horizons on the landscape (Ingold 1993).

Ranchers told me that they turned land into pastures not because cattle were highly profitable, but because "it's more like a savings business, if you're the owner of the land," as one commented. The savings could even accrue from leaving pastures empty. Part of the strategy constituted market speculation: if they bought the land cheaply, prices would eventually go up. "Having four cows on the land is saving money, because sooner or later someone else will come and pay you 20 
million [pesos/hectare]," one rancher told me. This is the epitome of what in Colombia is called the lote de engorde (fattening plot), a parallel between the fattening of cows on pasture and the growth in value of a plot of land over time. While the crops and orchards planted by small farmers indicated a temporality of family provisioning, the pastures represented a different future orientation-toward the purchase and sale of fattened cattle, but even more toward land markets themselves.

For some, this activity made possible another kind of "savings": money laundering. One landholder described the strategy to me: "Drug dealers, guerrillas, paras, what might they do with huge volumes of bags . . . of cash that they had was buy land. Then it was safer to have land than to have bags of dollars under your bed." Land could also serve as cover for drug operations, particularly transit, as Urabá is home to a key confluence of rivers, roads, and ports used for drug export.

While landholders' decisions would appear to be largely speculation on the market, they also relied on complicated forms of speculation on future legal regimes and regimes of violence. First, there was the idea that if landholders bought land cheaply and maintained possession, paramilitaries would subdue the guerrillas and land prices would go up. Second, there was speculation that paramilitaries would continue to have influence on state institutions. And third, there was the assumption that there would not be enforcement against the legal fictions landholders had employed to title properties.

Some landholders also hedged these bets by facilitating peasant possession of plots, occasionally in collaboration with paramilitaries, who used possession to cultivate a social base of supportive locals. One of the most important means of building this base occurred in the form of repoblamiento (repopulation), or what some paramilitaries called reforma agraria (land reform).

Jorge, a displaced farmer in his fifties, recounted to me how he had been living in town when men came offering land to displaced families to grow plantain. His and dozens of other families signed up. They formed a plantain export association, to which title was transferred from a local paramilitary. The title, however, proved false, backdated to circumvent legal limitations on individual landholdings and give the impression that the plot had been legally acquired prior to la violencia. Although the false title later came to the attention of several government ministries, they were reluctant to challenge it, given that so many displaced families were living there. In this way, paramilitaries provided the possibility of land possession to displaced farmers, while using repopulation projects to avoid title challenges. 
Ranchers also used gifts of possession to secure local support or, as one rancher put it, to stop peasants from becoming guerrillas. Some gave displaced farmers long-term loans of land or permission to farm plots for given growing cycles. Others did not grant permission but forbearance, such as the rancher who could have removed Cristina and Ernesto but chose not to. This situation placed small farmers in permanent uncertainty, as ranchers could remove them at any time. And indeed, ranchers frequently employed police to remove small farmers, often from the very land from which they had been originally displaced. On the other hand, every day that farmers managed to stay on the land put them in closer reach of a legal claim to posesión.

In general, landholders understood themselves to be incurring risks that were simultaneously personal, financial, legal, and political. One told me that “we've risked not only our lives but also our wealth, and we've built this country." Facing restitution, many landholders complained of having invested in land and the region in a context of state abandonment, only to be expropriated by the state through a dubious peace-building project. In this sense, landholders-like peasant possessors - speculated on uncertain legal, political, and market regimes through land. Facilitating peasant possession of land through loans, gifts, and purported land reform formed part of these speculative strategies, along with large-scale land acquisitions.

Armed actors, landholders, and small farmers negotiated uncertainties about the future by employing different iterations of property-from possession to title- to manage the risks of land transactions. As Annelise Riles (2011) notes, private legal technologies provide ways of handling temporal uncertainties in situations of market risk. Here, people used property to manage risks from market fluctuations, as well as from legal shifts and physical violence. These moves constituted legal conjectures about how land might be allocated in a potential future peace, betting on whether peasant possessions might become formalized, landholders' acquisitions would be questioned, and landholders might face imprisonment. Despite significant differences in power between social groups, speculation through property over land constituted a common framework for managing the deep uncertainties generated by the conflict - and, later, the prospect of peace.

Possession becomes a crucial form of speculation during conflict because it lies at the interstices of legality, the market, and violence, simultaneously evoking a legal form of property and illegal trespass. Under conditions of uncertainty, speculative possession can be used to stake a claim in the absence of or alongside other 
property forms. It can also serve as a form of dispossession, deepening ambiguities around who might be considered a victim or a benefactor.

Crucially, even as acts of possession stake claims on the future, they are not always oriented toward more legal formality, as suggested in other theories of land speculation (Campbell 2015). While moving toward more formal land tenure at times was a goal of possession in Urabá, it was precisely the ambiguously legal nature of possession that made it an attractive form of speculation in its own right, not only as a step toward title. Speculative possession was in this sense more a conjecture about formal legal regimes and their future enforcement than necessarily a move toward them.

\section{HISTORICAL LAND INVASION}

These conjectures concerned potential futures, but they also drew on historical efforts at land possession in the region. The temporality of speculative possession thus simultaneously called up the future and the past. This section explores land invasion as a key historical form of speculative possession.

Although Urabá had been a site of extractive projects for centuries (Parsons 1967), the second half of the twentieth century showed significant growth, sparked by the completion of a road from Medellin to Urabá and the establishment of the banana industry. A number of the region's landowners arrived in the 1960s to work for international banana companies or to buy plantations. Laborers migrated from neighboring departments to plant, cut, pack, and transport bananas to Urabá's port of Turbo for export.

The 1980s were years of tremendous bloodshed around the plantations, where banana workers lived in camps. Unionized workers frequently found themselves targeted. Many moved to town, often taking land through invasión. As a legal and colloquial category, invasión involves taking land without prior agreement from the legal owner. Hundreds would do an invasion, setting up overnight on large private plots. Left-wing political groups and armed actors also became involved in Urabá's urban invasions, seeking political base (García 1996).

Invasions would appear to contradict the interests of local landholders, but economic interests and the fear that unionists might double as guerrillas pushed some landholders to support invasions. Happy to dismantle camps they saw as guerrilla breeding grounds, some plantation owners incentivized urban invasions by their workers, even allowing them to take materials from camps - toilets, shingles, bricks - for their new homes in invasions. Landholders who had their urban plots invaded turned it into a market opportunity. One Urabá businessman told 
me that "the land owner also cleverly acted dumb and let his land be invaded . . saying [to the mayor], there's an invasion, you need this land . . . buy it from me. And they made a big business out of this . . . and it was the state's responsibility to legalize those [invaded] neighborhoods." Another noted that "those lands weren't worth anything precisely because of the violence, and the state paid really good prices." Land possessors and large landholders each engaged in a speculative strategy to take advantage of the municipal government's need to respond to invasions.

Rural invasions were also common during this period in Urabá. Perhaps the most famous was La Coldesa, a Dutch-owned African palm farm invaded by hundreds of small farmers in 1986 (García 1996). Small farmers also took other plots belonging to plantation owners and ranchers, in some cases later receiving title. Some found support in guerrilla groups such as the Popular Liberation Army (EPL), which had a committee devoted to invasion support.

Small farmers in the area around Ernesto and Cristina's plot were intimately tied to this history of invasion. Several of them in the 1980s had participated in an urban invasion in Urabá associated with the Unión Patriótica (UP), a left political party founded in peace negotiations between the FARC and the Belisario Betancur administration. ${ }^{6}$ From there, they had also organized to invade rural plots. But maintaining possession did not prove easy, given opposition by landholders and, later, by paramilitaries who accused small farmers of taking possession in collaboration with guerrillas. Virgilio, a small farmer in his sixties who had participated in urban and rural invasions in Urabá, narrated his account of this history to me:

We came to La María [farm], fifty plot holders stayed there, and there was a mortgage on it . . . they said that if they paid the debt they could keep the land. But those representatives came from [a UP-associated invasion]. They were disappeared. Other people started to get afraid, it was bad. Four hundred families said that they were going to La Libertad [farm]. I went to La Libertad. We had ten hectares with corn . . . the owner there made a proposal, for us to come to El Coco [farm], giving us [the land] ... so that we wouldn't invade [La Libertad], and would go instead to El Coco . . . . We went there . . later the police called us to a meeting, [saying] that we were going to have to give back the land because the head-choppers [paramilitaries] were coming. ... I had corn, rice, cassava, plantain, those fields were full of food . . . and it ended up in the hands of [a rancher]. He started to attack people, burn huts, it was a huge mess. 
This history demonstrates the complex regimes of possession in which people operated. At each opportunity they have to establish themselves, they confront violence, keeping them in a cycle of recurring possessory efforts. One landholder finds a gift of possession strategic, however, granting them El Coco in exchange for leaving La Libertad. Virgilio told me that the landholder intended to sell La Libertad, and an invasion would have made a sale impossible. This made the gift of El Coco to invaders a financially strategic move.

People conducted invasions out of necessity, but they also became enrolled in political projects through them. Some took possession because they opposed land concentration in the hands of the wealthy. Guerrillas and left-wing groups generally shared this notion, and often derived political gains from supporting invasions, as did elected officials who helped legalize them. Finally, displaced people also became enrolled in the projects of landholders, who used invasion as a market opening.

Invasions thus served as early forms of speculative possession, through which different actors staked claims on the future - and helped to shape it - in a time of colonization and political uncertainty. With the increase in violence in the late 1990s, the ubiquity of rural invasions receded, as invaders were displaced and moved to expanding paramilitary-dominated urban housing markets. But invasion remained a crucial element of the legal and political repertoire that the poor drew on in response to projects like restitution.

In Caitlin Zaloom's (2009) analysis of financial knowledge, she argues that people draw on the history of the yield curve to establish its relevance in forecasting the future. Similarly, speculative possession drew past and future together, with historical invasions helping establish land possession as a central mode of staking a claim on the future. These invasions also served as a source of political and legal strategy, informing different actors' understandings of how possession might be enacted and related to other forms of property. Historical invasion helped define the scope and reach of speculative possession of land and the central role it could play in rendering the space between war and peace material.

\section{REORDERING IN THE SHADOW OF THE POST-CONFLICT}

When the land restitution program was established in 2011, it layered new legal and political regimes onto the complex, shifting patterns of speculative possession already in place. One of the most notable initial effects of restitution was the rearrangement of expectations of state intervention in local land economies. Restitution almost immediately became an integral part of these economies, shift- 
ing future panoramas in anticipation of which paramilitaries, state actors, businesspeople, and displaced persons made speculative moves.

Ernesto and Cristina, along with thousands of others in Urabá, filed a restitution claim. At the beginning of the process, there were high expectationsand fears on the part of large landholders - that the state would return land to peasants. But time dragged on, with few resolved cases. Soon, groups of displaced people organized to retrieve their former lands on their own through collective takings. I use collective taking rather than invasion here, as those conducting collective takings often considered themselves to have a rightful claim to the land (as opposed to invaders, who intentionally took land that was not theirs).

As the takings unfolded, I was visiting a claimant named Juan in his tiny shack in an urban invasion when his phone rang. "Se metieron?! [They went and took it?!].” He had just been voicing his frustration with the time his restitution claim was taking. And now here was news that others were retaking land near where his plot had been! They had put up poles covered with black plastic and planted rice and corn - retaking possession of plots they had lost in the very way they had first acquired them. He trembled with excitement. "Let's go find other claimants," he said, "to see what they think." We set off through the dirt roads of the invasion.

The first stop was Carmen's. "Better for them to give us the money, right?" she argued, uninterested in returning to the land and hoping for cash restitution. "My hands are arthritic now," she said, holding up her painted nails. "Who's going to work out there?" We left, Juan disdainfully mumbling about people wanting money rather than land as we walked to our next stop, Emilio's. "I don't want problems," Emilio said immediately. "How many are out there?" Not trusting Juan to tell him the truth, he called Marta, who was part of a collective taking. "Put up a cambuche for me!" he said to her, clearly wanting the land, but hesitant to risk it. Emilio's wife cautioned, "life is better than not having it!"

We went to the park to find César, who had just arrived, exhausted from his job pruning banana plants. "This doesn't seem legal to me," he said. "We have a case and we don't want to damage it . . . to lose our rights." Juan rubbed his face, stressed. "He doesn't listen!" César complained, repeating that "we have to do this the legal way." We did invasión in the past, yes, he said. "But everything we're doing to get the land back has to be legal." "If we do an invasión, there comes another displacement, that's what comes." This worry was reinforced by the restitution program's opposition to the collective takings, and its urging that claimants wait for the resolution of claims in court. 
Later, Juan complained to me about César's use of the word invasión to describe the taking. "He says it's invasión . . . but it's not invasión. If they have title, it's invasión, but these were baldíos . . . we are the owners of that, they [the ranchers] are the ones that did an invasión!” This disagreement put into question the legality of three land acquisitions: that of Juan and César decades earlier (were they baldios legally acquired through possession or not?), of the ranchers in the 1990s (was it a legal purchase or a forced dispossession?), and of collective takings in the moment (was it a legal retaking of dispossessed land or an illegal invasion?). These acquisitions, and their tenuous legality, illustrated a historical pattern of speculative possession and its recasting in the shadow of the post-conflict.

Both those supporting and opposing these new takings carefully determined their moves, considering potential consequences for restitution claims and violent recrimination. Everyone understood that restitution had put landholders' ownership into question. But what would the restitution program determine about claims, and when? What would be the consequences for takings in the meantime? By failing to conduct a taking, might people lose the opportunity to stake a future claim on the land? The ambiguity around the roles played by those opposing takings increased fears of violence, which those conducting takings surmised could come from multiple people who might be colluding against them-ranchers, ranch hands, paramilitaries, the restitution program, the police.

Those conducting takings had a variety of orientations toward restitution. Some had been inspired by the process, but felt frustration at the delays with the claims. Others thought taking possession would advance their restitution claims by demonstrating they truly needed land. Still others considered the takings simply to anticipate the eventual success of their claim. Across the board, however, the physical form that collective takings took explicitly recalled earlier histories of invasion. As Kregg Hetherington (2011) observes, the shifting of land politics into a state bureaucracy intensified, rather than erased, the importance of action on the ground.

From the perspective of people like Juan, possession had led to successful claims to land in the past, and was a way to stake a claim on it again for the future. But people like César worried about staying within the bounds of the law. While many claimants had initially acquired their plots via invasion, they sensed that to succeed in restitution, they could no longer employ those tactics. Claimants recognized that clean victimhood was important to the restitution program's imagination of a rightful claim. One had to be a victim, not an invader-even if prior 
invasion was the very reason they had a claim at all. Injury, not politics, had to be the claimant's identity (Brown 1995).

The boundaries of victimhood also pushed claimants to conduct land negotiations in anticipation of unsuccessful restitution cases. As news of collective takings spread, I visited a claimant, Mariela, who was chatting with a visitor named Elkin. Mariela told me Elkin's father was the real dueño (owner) of her plot, having felled the forest to build a farm before his displacement by guerrillas in 1988 . Mariela invaded the plot in 1994, but fled in 1997 during the violencia. She had recently retaken possession of the plot from a rancher. Elkin told Mariela that his restitution claim for the plot had been rejected; the program only accepted claimants displaced from 1991 onward. Now, he said, his only option to get land was to negotiate with her. They agreed to split the plot, counting on a later state ratification of their deal. After he left, Mariela said proudly, "See? He doesn't get in touch with [the rancher], but instead with me. That's how it should be. And then we negotiate." In this way, collective takings in anticipation of restitution made speculative private land deals possible and shifted negotiating authority from landholders to possessors, precisely because restitution cases had not been resolved.

People also made decisions not to invest in homes and farms, given their uncertainty about restitution. Mariela, for example, lived in a humble wooden home purchased with state reparations money for her son's murder by paramilitaries. Now that restitution was underway, she wondered, who might make a claim on this house? "I bought it from a second owner, and there was a first owner who might have been forced to sell at a low price. So I'm not going to fix it up until I have the title." She noted that "those who are aware of what's happening are selling now" to buyers unaware that the homes might be subject to restitution claims.

In anticipation of potentially successful restitution claims, some landholders let weeds take over pastures. Several faced mounting legal pressures, as restitution called into question the legality of their holdings. "Money invested is money risked," one landholder told me. In response, some displaced people began planting crops in the fields. Landholders tried to push the removal of these people by the police, and rumors circulated of violent recrimination. But efforts to oppose takings were fewer than in the past, given landholders' concerns about legal consequences. The public prosecutor's office had opened investigations on some landholders for paramilitary financing, and had arrested others on charges of forced displacement. Landholders meanwhile complained that all they wanted was "legal security" for increasingly risky land investments. 
Landholder arrests were joyful news to some, but they created opposition from others to both collective takings and restitution. Many landless people depended on landholders as patrons for jobs, money, or loans of land. There was talk that some landholders might sponsor sympathetic possessors on their land, in response to the takings. Other landless people did not materially depend on landholders, but understood them as necessary interlocutors to maintain calm.

While patterns of possession in the wake of restitution often concerned these medium-term futures, there was also speculation about long-term horizons. After restitution, what would happen with the land? Few expected that the restitution program's notion of a fixed map of returned peasants would come to pass. Restitution officials themselves doubted this, in part because titling would provide precisely what landholders desired: legal security. This would create more easily transferable land assets, mirroring the solution Hernando de Soto (2000) prescribed for the developing world.

Many officials expressed frustration over this situation. "Estamos legalizando el despojo [We are legalizing dispossession]," one restitution lawyer told me despondently. He anticipated that peasants receiving title through restitution would simply sell it after a two-year moratorium on sales, likely to the same large landholders, resulting in a second "dispossession." Except this one would be legalized, facilitated by restitution itself. One rancher also anticipated this result, telling me "the state's problem has always been not providing assistance so people can work the land. This will happen again here, and then I will just buy the land [lost through restitution] again afterward!” When I mentioned this concern to an Urabá land activist, however, he considered it a typically bogotana (Bogotá person's) worry. "Who's to say it's not OK for people to get their land back and then sell it?" he asked. "That doesn't mean they don't deserve to get back what was stolen from them." As Tania Murray Li $(2014,4)$ observes, those who lose land cannot - or do not necessarily want to — return to the "past condition imagined to be more wholesome."

As reordering projects like restitution unfolded, new forms of speculative possession emerged, alongside reshaped versions of historical speculative forms, such as invasion. In actions like collective takings, possessors drew on their experience with speculative possession in past moments of uncertainty, such as the invasions of the colonization boom in the 1970s and 1980s. Many of these invasions were later titled to possessors, giving them faith that - as the adage proclaims possession was nine tenths of the law. In the space of ambiguity between peace and war, this conviction reemerged as the rewriting of property rules became 
central to the imagination of a post-conflict future. Staking a claim on this future involved, much as during colonization, possession through grounded physical presence - planting rice and corn and building a cambuche.

People also learned from the past that taking possession involved legal, economic, and personal risks. In Kristin Peterson's (2014) theory of “derivative life," people manage environments of chronic risk by speculating on what she calls "life's chances." For her, these chances are undergirded by fundamental economic instabilities. In Urabá, uncertainties not only about the market but also about legal regimes and regimes of violence meant that possession became a form of speculation on land, and simultaneously on life itself.

Long histories of land possession and dispossession contributed to the high stakes of new forms of speculative possession. On the one hand, possessors like Juan risked violent retaliation, as takings called into question landholders' prior acquisitions and future ownership. At the same time, these histories gave possessors reason to hope. If possession had led to success during the colonization boom, then why not try again? They had everything to lose. But they also stood to gain both the land they had lost and a rearrangement of power in the region should possessors have widespread success in recuperating land. They drew inspiration from such rearrangements during the colonization of Urabá, when possessors gained access to land through invasion, their speculation both anticipating and shaping legal futures. New forms of speculative possession thus formed part of what Maria Paula Saffon and Fabio Sánchez (2019) describe as a cyclical historical relationship among the legal recognition of land possession, violent dispossession, and claims to recuperate land. Possession held historical weight at the same time as it proved a central mode of staking a claim on an uncertain future.

In their theorization of anticipation, Adams, Murphy, and Clarke (2009, 249) note that "what all speculations share is the orientation towards and claim to the future as that which matters." What becomes evident in theorizing speculation through land is that speculation is defined not only by its orientation toward the future as that which matters, but also by making claims on the future through that which matters: land. As peace is continually deferred, people attempt to ground themselves through the possession of land, rendering life more concrete even if not less risky. Although history has taught people how ephemeral possession can be, it has also taught them that laying claim to land through possession is a critical mode of negotiating power and enacts a potent material demonstration of its distribution. 
In this sense, it was through possession of land that people attempted to make material the ambiguous space between war and peace. It is this rendering material through possession - not a rendering formal through title- that frequently forms the substance of speculation in the shadow of the post-conflict. While possession indexed a more tenuous hold on land along scales of formality of tenure, it represented for many the most material, concrete manifestation of a claim on the future.

In Jain's theory of "living in prognosis," the rendering material of the space between life and death involves multiple temporal orientations at once: toward a past that was not what it seemed and multiple versions of the future. The calculations involved in speculative possession similarly tack temporally between memory of the past and a potential future peace. And yet they also move through more discontinuous temporalities, such as diverse past political practices of occupation; the life cycles and potentialities of crops, cattle, and pastures; and conjectures around the many potential futures of eviction, restitution, titling, gain, and loss.

\section{CONCLUSION}

In Zeiderman's (2016, ix) analysis of temporal politics in Colombia, he emphasizes the durative, open-ended quality of the temporality of endangerment. As with anticipation of future harm, in the shadow of the post-conflict, it is never clear when, or if, peace will arrive, as the possibility of violence sits in persistent ambiguity with the possibility of peace. This shadow has a continually receding temporal horizon, creating conditions of deep uncertainty - the "epistemic murk" (Taussig 1984, 492) that imbues this iteration of the near future. The durative nature of this ambiguity has created a field of speculative possibilities for everyone from dispossessed claimants to wealthy landholders. Actions such as collective takings by the landless and disinvestment by ranchers have been structured around persistent guesswork about what might be dealt to whom in the future.

In response to Guyer's provocation regarding the near future, Zaloom (2007) asked how it is instantiated and made palpable. She finds answers in neuroeconomics, as other anthropologists of speculative futures find them in financial and scientific pursuits. An examination of the terrain of the near future in Colombia, however, demonstrates that the answers are found most clearly in land. In the early years of restitution, people expected property rules to be rewritten, but the potential outcomes remained unclear - even for the very state bureaucrats charged with rewriting. In this situation of deep uncertainty, property over land became the common object of speculation, through which bureaucrats, paramilitaries, dis- 
placed people, and landholders enrolled each other in overlapping projects that produced new and reconfigured past processes of dis/possession, violence, and legal innovation. In particular, the physical possession of land-long understood as a way of working toward other forms of property over time-became a primary means of staking a speculative claim on the future and of rendering material the expanding temporal space between war and peace.

Why would people use possession - a relationship to land that is itself ambiguous in terms of its legality and formality - to make this uncertain space more concrete? On the one hand, it represents the clear, public staking of a claim through physical presence. This aspect of possession made it a critical element of efforts to acquire land during the colonization of Urabá, and then later in the context of restitution, when the allocation of land once again appeared to be up for grabs. Even though possession could be characterized as illegal trespass, it could simultaneously constitute a legitimate form of staking a claim to prior or future right, and even working toward title. It also exacerbated uncertainties about the legitimate owner of certain plots. This actually contributed to the solidity of some claims to contested plots, particularly when claimants used possession to challenge the distribution of land among large landholders or the legality of its acquisition.

Why would possession emerge in that moment with such force? Many small farmers lost their land in la violencia, nearly twenty years earlier. The uncertainties produced by a potential post-conflict peace are key to answering this question. Since la violencia, the future has been somewhat certain in Urabá - there would be war, followed by more war. Attempts by the displaced to repossess land would be met with violence and little state support. But the national reorientation toward peace, in which property rules would ostensibly be rearranged, created enough expectation to shape action, even for those who doubted the arrival of peace. The successful titling of land invasions during the late twentieth century persisted in local political memory as the means for staking a speculative claim under conditions of such uncertainty - and perhaps, as Ernesto surmised, gain something more. As a result, even as formal title became theoretically more accessible through restitution, possession took on renewed importance as a hopeful orientation toward the future.

The object possessed — land — was also understood across social groups to be the most concrete means of negotiating power and establishing a future in the region. Land had long been the subject of struggle in Urabá, as it had throughout Colombia. A plausible claim to it indexed a victory of sorts in both particular conflicts, such as those between claimants and large landholders, and in the conflict 
writ large. Cristina's comment that ranchers would "see a future" in the young teak trees where she had taken possession - despite threats to her life and her claim to the land - provides just one example of how even a tenuous, contested claim to property over land represented a shot at the future in a way that little else did. The fact that land was perceived to be concrete, even as people's relationships to it remained unstable, rendered it an exemplary object of speculation.

Land's role in the conflict, and in an aspirational peace, also rendered it the repeated subject of state intervention. The reordering of property, from the legalization of invasions to the restitution of land, opened a field of speculative possibilities that had stakes both for individuals and for the balance between war and peace. More than ceasefires, a truth commission, or the participation of the FARC in politics, it was the expectation that the state would reorder property in land that was the focus of speculation in Urabá. People made conjectures about these interventions, as they allowed for land to come into or slip through their hands quickly, and they had significant implications for ongoing violence. That so many past state efforts to reorder property yielded ambiguous results - the legalization of invasions had initially facilitated access to land for small farmers, but state response to the subsequent acquisition and consolidation of land by ranchers was minimal — deepened the importance of state interventions around property as critical focal points for speculation.

The nature of land as simultaneously concrete and unstable, combined with the possibilities and risks of state interventions into property over land, granted land both potentiality and uncertainty. In Gisa Weszkalnys's (2015, 623) discussion of oil exploration, she theorizes speculation as an "observation of potentiality" that offers a mode of participation in opportunities opened by "obscured matter": material yet unproven oil reserves. She productively moves beyond speculation as something largely financial to the ways in which the material world, in all of its ambiguities and uncertainties, becomes an object of speculation. Similarly, land, in all of its particular ambiguities, became the material basis for speculation in the shadow of post-conflict Colombia. And yet it is not its existence as obscured matter, but rather as the most visible and apparently concrete form available, that grants land its uncertain potentiality. It is precisely its presumed stability that gives land its speculative value.

Conceptualizing speculation through land opens up speculation not only as a market disposition but also as a legal analytical position, in which law is structural to conjectures about the future. Speculative possession is about staking a claim, and it is also about creating and preserving options of potential property claims 
that might be made - to title, restitution, or ongoing possession. In this sense, it is about gauging what legal regimes might offer in the future and about opening a space of argument within them. Like Mnookin and Kornhauser's (1979) bargaining in the shadow of the law, this involves projections of what one might stand to gain or lose, and negotiating accordingly in the present. But it is also about creating space for one's own potential future claims. Possession of land constitutes the active form of opening this space of argument. While Weszkalnys (2015) finds that legal instruments are "gestures" of uncertain futures, I argue that law is in fact structural to speculation as an analytical mode.

The temporality of speculation in this context is not exclusively financial or prophetic but also — and perhaps primarily_legal. The possibility of possession, title, and other forms of property depend on compliance with legal-temporal parameters, of which land possessors were generally aware. They made conjectures about potential futures on the land based on the time that elapsed without incident, the crops that remained undisturbed or were destroyed, their compliance with legal rules for formalizing their claim, and their past experience of successful invasion. Those conducting takings, as well as large landholders, assessed how restitution might affect them and whether landholders' acquisitions would be questioned, taking action accordingly. These are conjectures about formal legal regimes within informal spaces that, as Peterson (2014) demonstrates, are crucial to how speculation operates. They also imply a consciousness of overlapping legal temporalities that people use to assess potential futures and take material action in the present, informed by the past. In the process, past, present, and future repeatedly fold into each other, producing the particular temporal disposition of the shadow of the post-conflict.

This temporal disposition is foundational to many sites that, like Colombia, find themselves in the long, murky limbo between conflict and post-conflict (Rojas Pérez 2008). This is often a legal limbo in the formal sense-of peace agreements, amnesties, international criminal responsibility, constitutional transition. But it is also a legal limbo in the everyday sense, in which citizens on the ground are unsure precisely how and when legal regimes might change and what they might gain or lose as a result. This uncertainty creates the conditions for speculation to proliferate, particularly on the likely future objects of legal intervention. In Colombia, the primary object in this respect is land.

The durative, expandable nature of the near future in Colombia is thus intimately and inextricably tied to property over land. As the promise of peace sits on the horizon, land becomes an object of speculation par excellence, based on 
conjectures about what that peace might hold in store. Yet that very speculation continues to feed the war in places like Urabá, deepening its intractability. As the state intervenes to reorder property in land in the very places where it has played a central role in the war, new conflicts emerge, continuing cycles of possession and dispossession that do not heed the call to a clear transition from war to peace. As in other post-conflict sites, the issue the war is "about" (Shaw 2015) thus becomes the very thing that has the potential to bring peace but does not, creating fertile ground for speculation in the long, expanding shadow of the post-conflict.

\begin{abstract}
In Colombia's attempts to bring its decades-long conflict to a close, the state engaged in a broad endeavor to bring about a new era: the "post-conflict." Land restitution, which aims to return and title land to those who lost it in the conflict, was billed as part of the path to peace. In the shadow of the post-conflict, however, restitution has given rise to speculation on uncertain market and legal regimes, as well as regimes of violence, which I explore drawing on ethnographic fieldwork in the region of Urabá. Speculative possession of land calls up historical forms of possession as well as potential futures, defining this shadow as peace is continually deferred. [speculation; land; property; conflict; possession; temporality; Colombia]
\end{abstract}

\title{
RESUMEN
}

Los intentos por terminar el largo conflicto armado en Colombia incluyen grandes esfuerzos por parte del Estado colombiano orientados a producir una nueva época: el "posconflicto". La restitución de tierras, una política que aspira devolver y titular tierras a los que las perdieron por causa del conflicto, fue promovida precisamente como parte de dicho esfuerzo hacia la paz. A partir de trabajo etnográfico en la región del Urabá exploro como, en la sombra del posconflicto, la restitución de tierras ha traído consigo diversas formas de especulación en torno a regímenes jurídicos, económicos y de violencia. En este contexto, la posesión especulativa de tierras simultáneamente invoca formas históricas de posesión así como futuros posibles, definiendo la sombra del posconflicto mientras la paz continuamente se difiere. [especulación; tierra; propiedad; conflicto; posesión; temporalidad; Colombia]

\section{NOTES}

Acknowledgments My thanks go first and foremost to the many people in Colombia who welcomed me into their homes and lives over the course of the research on which this article is based. Though many of them must remain unnamed here, this research would not have been possible without their generosity of time, thought, trust, and friendship. I thank my colleagues at the Center for Law, Justice and Society (Dejusticia) and the Universidad de los Andes Law School, where I was affiliated during my research, for many years of sustaining conversations and collaborations. I also thank the University of Chicago Department of Anthropology, the Harvard University Department of African and African American Studies, and the American 
Bar Foundation for the supportive and collegial environments they provided for writing and revision. I am grateful for comments on versions of this article and its argument from Helena Alviar, Alejandra Azuero, Diana Bocarejo, Lee Cabatingan, Nicholas Carby-Denning, Jean Comaroff, John Comaroff, Nate Ela, Ali Feser, Andrea Ford, Eric Hirsch, Julieta Lemaitre, Joe Masco, Amy McLachlan, Agnes Mondragón, Erin Moore, Stephan Palmié, Kristin Peterson, Justin Richland, Diana Rodríguez Franco, Paula Rodríguez, Steven Schwartz, Jeremy Siegman, Kaushik Sunder Rajan, Christien Tompkins, and Austin Zeiderman, as well as from several anonymous reviewers and the Cultural Anthropology editorial collective, who improved the article substantially. I also benefited from feedback received on earlier versions of this essay from participants in the American Bar Foundation doctoral fellows workshop, the Northwestern Sociology Colloquium, the University of Chicago Workshop on Latin America and the Caribbean, the MaGrann Conference at Rutgers University, and the annual Latin American Studies Association International Congress, as well as at a workshop hosted by the Zolberg Institute on Migration and Mobility at The New School for Social Research. Different stages of the research and writing of this article were funded by the Social Science Research Council; the Wenner-Gren Foundation; the Inter-American Foundation; the Land Deal Politics Initiative; the University of Chicago Center for Latin American Studies, Department of Anthropology, and Pozen Family Center for Human Rights; the American Bar Foundation; and the National Science Foundation under Grant No. SES-1655497.

1. Names and identifying details of individuals and some locations have been changed to protect anonymity.

2. When land restitution began, there were already multiple legal regimes in place to deal with displacement and dispossession, including statutes and judicial precedent on attention to the displaced population, agrarian reform laws and institutions, and the existing transitional justice regime designed to demobilize paramilitaries.

3. While the term invasion is not a precise legal translation of invasión, I use it here to give a sense of the physical taking of possession implied in invasión, as well as its proliferation in gray zones of legality.

4. I follow local usage throughout this article.

5. This ambiguity was pervasive throughout my fieldwork. In this article, I refer to individuals as they presented themselves to me.

6. Thousands of UP members were murdered and disappeared in the 1990s, largely eliminating the party.

\section{REFERENCES}

Adams, Vincanne, Michelle Murphy, and Adele E. Clarke

2009 "Anticipation: Technoscience, Life, Affect, Temporality." Subjectivity 28, no. 1: 246-65. https://doi.org/10.1057/sub.2009.18.

Ballvé, Teo

2013 "Grassroots Masquerades: Development, Paramilitaries, and Land Laundering in

Barad, Karen Colombia." Geoforum 50: 62-75. https://doi.org/10.1016/j.geoforum.2013.08.001.

2007 Meeting the Universe Halfway: Quantum Physics and the Entanglement of Matter and Meaning. Durham, N.C.: Duke University Press.

Bergquist, Charles, Ricardo Peñaranda, and Gonzalo Sánchez G., eds.

2001 Violence in Colombia, 1990-2000: Waging War and Negotiating Peace. Wilmington, Del.: Scholarly Resources.

Brown, Wendy

1995 States of Injury: Power and Freedom in Late Modernity. Princeton, N.J.: Princeton University Press.

Campbell, Jeremy M.

2015 Conjuring Property: Speculation and Environmental Futures in the Brazilian Amazon. Seattle: University of Washington Press. 
CMH (Centro de Memoria Histórica)

2010 La tierra en disputa: Memorias del despojo y resistencias campesinas en la Costa Caribe, 1960-2010. Bogotá: Taurus.

de Soto, Hernando

2000 The Mystery of Capital: Why Capitalism Triumphs in the West and Fails Everywhere Else. New York: Basic Books.

Duncan, Gustavo

2006 Los señores de la guerra: De paramilitares, mafiosos y autodefensas en Colombia. Bogotá: Editorial Planeta Colombiana.

2014 Más que plata o plomo: El poder político del narcotráfico en Colombia y México. Bogotá: Penguin Random House Grupo Editorial.

Fortun, Mike

2008 Promising Genomics: Iceland and deCODE Genetics in a World of Speculation. Berkeley:

García, Clara Inés University of California Press.

1996 Urabá: Región, actores y conflicto, 1960-1990. Medellín: INER.

Guyer, Jane I.

2007 "Prophecy and the Near Future: Thoughts on Macroeconomic, Evangelical, and Punctuated Time." American Ethnologist 34, no. 3: 409-21. https://doi. org/10.1525/ae.2007.34.3.409.

Hetherington, Kregg

2011 Guerrilla Auditors: The Politics of Transparency in Neoliberal Paraguay. Durham, N.C.: Duke University Press.

Ho, Karen

2009 Liquidated: An Ethnography of Wall Street. Durham, N.C.: Duke University Press.

HRW (Human Rights Watch)

2013 The Risk of Returning Home: Violence and Threats against Displaced People Reclaiming

Ingold, Tim Land in Colombia. New York: Human Rights Watch.

1993 "The Temporality of the Landscape." World Archaeology 25, no. 2: 152-74. https://

Jain, Sarah Lochlann doi.org/10.1080/00438243.1993.9980235.

2007 "Living in Prognosis: Toward an Elegiac Politics." Representations 98, no. 1: 77-92. https://doi.org/10.1525/rep.2007.98.1.77.

Lakoff, Andrew, and Stephen J. Collier

2008 Biosecurity Interventions: Global Health and Security in Question. New York: Columbia University Press.

Li, Tania Murray

2014 Land's End: Capitalist Relations on an Indigenous Frontier. Durham, N.C.: Duke University Press.

López, Claudia

2007 "La ruta de la expansión paramilitar y la transformación política en Antioquia." In Parapolítica: La ruta de la expansión paramilitar y los acuerdos políticos, edited by Mauricio Romero, 226-32. Bogotá: Corporación Nuevo Arco Iris.

McAllister, Carlota, and Diane M. Nelson, eds.

2013 War by Other Means: Aftermath in Post-Genocide Guatemala. Durham, N.C.: Duke University Press.

Mnookin, Robert H., and Lewis Kornhauser

1979 "Bargaining in the Shadow of the Law: The Case of Divorce." The Yale Law Journal

Nelson, Diane M. 88, no. 5: 950-97. https://doi.org/10.2307/795824.

2009 Reckoning: The Ends of War in Guatemala. Durham, N.C.: Duke University Press. 
Nordstrom, Carolyn

Parsons, James J.

2004 Shadows of War: Violence, Power, and International Profiteering in the Twenty-First Century. Berkeley: University of California Press.

1967 Antioquia's Corridor to the Sea: An Historical Geography of the Settlement of Urabá.

Peterson, Kristin Berkeley: University of California Press.

2014 Speculative Markets: Drug Circuits and Derivative Life in Nigeria. Durham, N.C.: Duke University Press.

Riles, Annelise

2011 Collateral Knowledge: Legal Reasoning in the Global Financial Markets. Chicago: University of Chicago Press.

Rojas Pérez, Isaias

2008 "Writing the Aftermath: Anthropology and 'Post-Conflict."' In A Companion to Latin American Anthropology, edited by Deborah Poole, 254-75. Malden, Mass.: Blackwell.

Romero Vidal, Mauricio, ed.

2011 La economía de los paramilitares: Redes de corrupción, negocios y política. Bogotá: Debate.

Saffon, Maria Paula, and Fabio Sánchez

2019 "Historical Grievances and War Dynamics: Old Land Conflicts as a Cause of Current Forced Displacements in Colombia." Documento CEDE No. 2019-21. http://dx.doi.org/10.2139/ssrn.3422907.

Scott, David

2014 Omens of Adversity: Tragedy, Time, Memory, Justice. Durham, N.C.: Duke University Press.

Shaw, Rosalind

2015 "Labors of Memory and the Post-Conflict Economy \#Transitionaljustice." Allegra Lab, January 20. http://allegralaboratory.net/labors-of-memory-and-the-postconflict-economy-transitionaljustice/.

Shneiderman, Sara, and Amanda Snellinger

2014 "Framing the Issues: The Politics of 'Postconflict."' Hot Spots, Fieldsights, March 24. Tate, Winifred https://culanth.org/fieldsights/framing-the-issues-the-politics-of-postconflict.

2015 Drugs, Thugs, and Diplomats: U.S. Policymaking in Colombia. Stanford: Stanford University Press.

Taussig, Michael

1984 "Culture of Terror-Space of Death: Roger Casement's Putumayo Report and the Explanation of Torture." Comparative Studies in Society and History 26, no. 3:

Theidon, Kimberly 467-97. https://doi.org/10.1017/S0010417500011105.

2007 "Transitional Subjects: The Disarmament, Demobilization and Reintegration of Former Combatants in Colombia." International Journal of Transitional Justice 1, no. 1: 66-90. https://doi.org/10.1093/ijtj/ijm011.

2013 Intimate Enemies: Violence and Reconciliation in Peru. Philadelphia: University of Pennsylvania Press.

Uprimny-Yepes, Rodrigo, and Nelson Camilo Sánchez

2010 "Los dilemas de la restitución de tierras en Colombia." Estudios Socio-Jurídicos 12, no. 2: 305-42. https://revistas.urosario.edu.co/index.php/sociojuridicos/article/ view/1373.

Weszkalnys, Gisa

2015 "Geology, Potentiality, Speculation: On the Indeterminacy of First Oil." Cultural Anthropology 30, no. 4: 611-39. https://doi.org/10.14506/ca30.4.08. 
Zaloom, Caitlin

2007 "Future Knowledge." American Ethnologist 34, no. 3: 444-46. https://doi. org/10.1525/ae.2007.34.3.444.

2009 "How to Read the Future: The Yield Curve, Affect, and Financial Prediction." Public Culture 21, no. 2: 245-68. https://doi.org/10.1215/08992363-2008-028.

Zeiderman, Austin

2016 Endangered City: The Politics of Security and Risk in Bogotá. Durham, N.C.: Duke University Press. 